\title{
Aleutian island arc magma production rates and mechanisms
}

\author{
Yongliang Bai ${ }^{1}$, Diya Zhang ${ }^{1}$, Dongdong Dong ${ }^{2}$, Shiguo $\mathrm{Wu}^{3}$, Zhenjie Wang ${ }^{1}$ \\ ${ }^{1}$ College of Ocean and Space Information, China University of Petroleum, Qingdao 266580, China \\ ${ }^{2}$ Key Laboratory of Marine Geology and Environment, Institute of Oceanology, Chinese Academy of Sciences, Qingdao \\ 5 266071, China \\ ${ }^{3}$ Institute of Deep-sea Science and Engineering, Chinese Academy of Sciences, Sanya 572000, China \\ Correspondence to: Yongliang Bai (yongliang.bai1986@gmail.com)
}

\begin{abstract}
The variation in island arc magma production rates and their influencing mechanisms are of great significance since island arc magma is considered a main source of continental crust growth. The island arc magma directly originates from the molten mantle wedge, and the mantle melting is driven by fluids or melts from the subducted slab. Slab dehydration flux mainly depends on the slab thermal structures, and subducted slab melting requires a sufficiently high temperature. For the Aleutian subduction system, the subducted Pacific Plate has diverse thermal structures due to the existing fracture zones, ridges and slab window, so it is an ideal region for arc magma production rate research. However, the previous estimations are based on seismic profiles that only provide magma production rates at specific regions of the Aleutian arc, and these results are
\end{abstract} controversial. Here, we design a magma production rate estimation method based on gravity inversion constrained by deep seismic profiles. The first overview map of magma production rates along the Aleutian arc strike demonstrates that the magma production rates have the same trend as the slab dips, and the peaks correspond to the subduction of the fracture zones and ridges. The potential mechanisms for these correlations are as follows: (1) Slab water flux at subarc depths increases with increasing slab dip. More fluid flux would induce more mantle melting, and so the arc magma production rates are increased.

20 (2) Water-rich serpentine is formed by hydrothermal alteration on or near the surface of the subducted slab when there are fracture zones. Serpentine decomposition at a depth of $80-120 \mathrm{~km}$ releases fluids in addition to the fluids released during normal slab dehydration. Therefore, more fluids induce more mantle melting and correspond a larger magma production rate. (3) The slab located in the Emperor Seamounts has a relatively high temperature and is also weak, so its melting is easier. Similarly, more slab melt means more mantle melt and a higher island arc magma production rate. 
https://doi.org/10.5194/se-2019-179

Preprint. Discussion started: 4 December 2019

(c) Author(s) 2019. CC BY 4.0 License.

(c) (i)

\section{Introduction}

Island arc magmatism is regarded as a main potential source of continental crust growth (Reymer and Schubert, 1984; Taylor, 1967; Rollinson, 2008; Ribeiro et al., 2015), since magmatic rock produced by arc magmatism is the main component of the continental crust (Rudnick and Fountain, 1995; Taylor, 1967; Rollinson, 2008). The formation of island arc magma is influenced by fluids or melts released from subducted slab (Schmidt and Poli, 1998; Grove et al., 2006; Yogodzinski et al.,

30 1995). Under certain temperature and pressure conditions, the hydrous minerals of the subducted slab dehydrate to release fluids (Schmidt and Poli, 1998; Grove et al., 2006; Yogodzinski et al., 1995). The fluids enter the mantle wedge under the island arc and induce the partial melting of the mantle wedge by reducing the minimum decomposition temperature of peridotite (Turner et al., 2000; Tollan and Hermann, 2019). In addition, the subducted slab can also melt at high temperature (Schmidt and Poli, 1998; Grove et al., 2006; Yogodzinski et al., 1995). Si-rich slab melting products rise to the mantle wedge

35 (Yogodzinski et al., 2013; Yogodzinski and Kelemen, 1998; Thorkelson, 1996) and interact with peridotite to form pyroxenite, which melts prior to peridotite due to its lower solidus (Yogodzinski and Kelemen, 1998; Liu et al., 2005; Zhang et al., 2012).

Island arc magma production rate refers to the newly formed magma volume on the island crust within a per unit length (1 km) along the arc strike and a unit time (1 Myr) (Dimalanta et al., 2002; Jicha and Jagoutz, 2015; Crisp, 1984). Because the subducted slab provides fluids and melts, its properties and geological structures, such as slab dips, fracture zones and ridges,

40 play important roles in island arc magma production rate variations. Therefore, mapping island arc magma production rates is helpful for understanding slab dehydration and arc magmatism processes and for understanding magmatism mechanisms (Clift, 2004; Jicha and Jagoutz, 2015). The estimation of island arc magma production rates requires determining magmatic thickness variations in the arc region and constraining the lifespan of magmatic activity (Reymer and Schubert, 1984; Dimalanta et al., 2002; Jicha and Jagoutz, 2015). Arc magmatic thickness used to be estimated based on seismic profiles (Steven Holbrook et

45 al., 1999; Lizarralde, 2002). However, the coverage of seismic surveys is very limited, mainly due to high costs. The limited seismic profiles cannot provide a sufficient overview of the magma production rate along the whole arc strike. With the rapid development of satellite technology, the accuracy of gravity data has been greatly improved (Sandwell et al., 2014). Gravity anomalies can be used to map the large-scale Moho undulations (Bai et al., 2019b; Wang et al., 2011; Tenzer et al., 2015). The crustal thickness can be determined by gravity inversion (Suo et al., 2016), which is an important parameter for estimating the 
https://doi.org/10.5194/se-2019-179

Preprint. Discussion started: 4 December 2019

(c) Author(s) 2019. CC BY 4.0 License.

(c) (i)

50 magmatic thickness and further for calculating island arc magma production rates.

There is no back-arc spreading behind the Aleutian island arc, so no residual arcs (Fig. 1), which means that the records of island arc magmatism there are mostly preserved at the present Aleutian arc (Jicha et al., 2011). The subducted Pacific Plate has diverse thermal structures (Levin et al., 2005) and slab dips (Hayes et al., 2018). In addition, there are fracture zones and ridges near the Aleutian Trench (Singer et al., 2007; Scholl, 2007), as well as slab window due to the tearing of the Pacific

55 Plate west of $173^{\circ} \mathrm{E}$ (Levin et al., 2005; Yogodzinski et al., 2001; Lay et al., 2017). Therefore, the Aleutian island arc is an ideal region for studying the island arc magma production rate and its potential influencing factors, including slab dips, fracture zones and ridges. However, the published magma production rates of the Aleutian island arc based on seismic profiles are controversial. The mean magma production rates of the entire Aleutian arc are (1) $33 \mathrm{~km}^{3} \mathrm{~km}^{-1} \mathrm{Myr}^{-1}$ (Reymer and Schubert, 1984), (2) $34 \mathrm{~km}^{3} \mathrm{~km}^{-1} \mathrm{Myr}^{-1}$ (Crisp, 1984), (3) $67 \mathrm{~km}^{3} \mathrm{~km}^{-1} \mathrm{Myr}^{-1}$ (Lizarralde, 2002), and (4) $89 \mathrm{~km}^{3} \mathrm{~km}^{-1} \mathrm{Myr}^{-1}$ (Jicha and

60 Jagoutz, 2015). The mean magma production rates of the intra-oceanic subduction parts of the Aleutian arc are (1) $75 \mathrm{~km}^{3} \mathrm{~km}^{-}$

${ }^{1} \mathrm{Myr}^{-1}$ (Steven Holbrook et al., 1999), (2) $61 \mathrm{~km}^{3} \mathrm{~km}^{-1} \mathrm{Myr}^{-1}$ (Dimalanta et al., 2002), and (3) $89 \mathrm{~km}^{3} \mathrm{~km}^{-1} \mathrm{Myr}^{-1}$ (Jicha et al., 2006).

The average rate of island arc magma production cannot reflect the local characteristics, so the variation in arc magma production rates along the island arc strike is estimated in this paper. Marine gravity anomaly data are used to map the arc

65 magmatism thickness; the latest geochemical dating results are used to determine the magmatic activity lifespan; then, the arc magma production rate variations of the whole Aleutian arc are derived. The potential influencing mechanisms will be discussed by analyzing the relationship between the magma production rate and the tectonic features.

\section{Geological Setting}

The Aleutian subduction zone is located in the northernmost part of the circum Pacific (Fig. 1), and it extends more than

$703000 \mathrm{~km}$ from the Kamchatka Peninsula on the west to the Alaska on the east (LEWIS et al., 1988; Jicha et al., 2006; Liu et al., 2018; Dimalanta et al., 2002). The convergence rates and incoming plate ages decrease from west to east (Müller et al., 2008; DeMets et al., 2010; Lay et al., 2017). The formation of the Aleutian island arc is related to a series of plate tectonic events in the northern Pacific region (Jicha et al., 2006; Steven Holbrook et al., 1999). At 59 Ma or earlier, the Kula Plate 
https://doi.org/10.5194/se-2019-179

Preprint. Discussion started: 4 December 2019

(c) Author(s) 2019. CC BY 4.0 License.

(c) (i)

subducted northward, and a convergent boundary was formed between the Kula Plate and the North American Plate (Jicha et

al., 2006; Liu et al., 2018). At 55 Ma, the northward subduction of the Kula Plate was hindered, and the previously formed convergence zone moved southward and formed the original style of the Aleutian subduction zone. The residual Kula Plate evolved into the Bering Sea (Fig. 1) (Jicha et al., 2006; Liu et al., 2018; Scholl, 2007). During the next 8 Myr, the Aleutian Trench was formed by the northward subduction of the Pacific Plate under the Bering Sea (Jicha et al., 2006; Liu et al., 2018). Between $47 \mathrm{Ma}$ and $40 \mathrm{Ma}$, the movement direction of the Pacific Plate changed from northward to northwestward (Jicha et

80 al., 2006; Liu et al., 2018). And the direction change led toward the transformation of the Emperor Seamounts direction (Scholl, 2007; Torsvik et al., 2017; Sharp and Clague, 2006). Hence, there was a bend between Hawaiian and Emperor Seamounts (Scholl, 2007; Torsvik et al., 2017; Sharp and Clague, 2006).

Geological structures west and east of $173^{\circ} \mathrm{E}$ of the Aleutian island arc are obviously different. West of $173^{\circ} \mathrm{E}$, the structure is more complex. There is a long strike-slip structure named the Bering Fracture Zone (BFZ), which is considered to

85 be the main tectonic plate boundary of the westernmost end of the Aleutian islands (Lay et al., 2017; Kogan et al., 2017). The BFZ separates the Aleutian island arc from the Kamchatka Peninsula (Jonathan M. Lees et al., 2000; Lay et al., 2017; Cross and Freymueller, 2008; Chekhovich et al., 2014) and the Komandorsky Basin (Jonathan M. Lees et al., 2000). The Pacific Plate subducts in northwestward inclines, and the oblique extent increases gradually from east to west along the Aleutian island arc (Davaille and Lees, 2004; Lee and King, 2010; Andrys et al., 2018; Lay et al., 2017). The BFZ is the westernmost end of

90 the Aleutian island arc, and here, the Pacific subduction direction is almost parallel to the strike of the present island arc (Lay et al., 2017; Yogodzinski et al., 1995; Chekhovich et al., 2014).

Another characteristic west of $173^{\circ} \mathrm{E}$ is that there is a slab window. According to geochemical experiments, adakite is found west of $173^{\circ} \mathrm{E}$ of the Aleutian island arc (Yogodzinski et al., 2001; Lee and King, 2010; Cai et al., 2014; Levin et al., 2005), which is a special high-Mg rock (Davaille and Lees, 2004; Yogodzinski et al., 2017; Kay, 1978), and its existence is

95 often regarded as evidence of a subducted slab tear (Levin et al., 2005; Cai et al., 2014). The shear wave velocity is low, and there is no deep earthquake in the Aleutian island arc region west of $173^{\circ} \mathrm{E}$ (Levin et al., 2005; Sdrolias and Müller, 2006; Lee and King, 2010). All of this evidence suggests the existence of a slab tear (Davaille and Lees, 2004; Cai et al., 2014; Lay et al., 2017). Therefore, the slab window is formed due to slab tearing (Yogodzinski et al., 2001; Levin et al., 2005). 
https://doi.org/10.5194/se-2019-179

Preprint. Discussion started: 4 December 2019

(c) Author(s) 2019. CC BY 4.0 License.

(c) (i)

In contrast, the structure type is relatively single east of $173^{\circ} \mathrm{E}$. There are some fracture zones (Fig. 1), and the subducted

100 slab dip increases from west to east overall. The axis of the Rat Fracture Zone (RFZ) is approximately $178^{\circ} \mathrm{E}$ (Geist et al., 1988; Singer et al., 2013). From 5 Ma to the modern stage of the Aleutian magmatic activity, the junction of the Amlia Fracture Zone (AFZ) and the Aleutian Trench deflects $300 \mathrm{~km}$ westward from below the Yunaska Volcano (Fig. 1) at $171^{\circ} \mathrm{W}$ and passes under the Seguam Island (Fig. 1) at $173^{\circ} \mathrm{W}$ at less than $1 \mathrm{Ma}$ (Singer et al., 2007).

\section{Methodology and Data}

The island arc magma production rate $\left(R_{\text {magma }}\right)$ is estimated via

$$
R_{\text {magma }}=\frac{\int_{B_{s}}^{B_{n}} T_{\text {magma }} d l}{L_{\text {magma }}} .
$$

where, $B_{n}$ and $B_{s}$ represent the arc boundaries; $T_{\text {magma }}$ represents the magmatic thickness of each sampling point; and $L_{\text {magma }}$ represents the magma activity lifespan. Therefore, the arc boundaries, arc magmatic thickness and magmatic activity lifespan are necessary to map the overview of the arc magma production rate along the island arc strike profile (Fig. 2).

\section{3.1 Mapping Magmatism Thickness}

The island arc is formed by accretion of magma to the original basement (Turner et al., 2000; Jicha and Jagoutz, 2015). Therefore, arc magmatism is the residual part remaining after removing the original basement from the present arc crust. The original basement thickness is set to $6 \mathrm{~km}$, which is the mean thickness of the residual Kula Plate (Jicha et al., 2006; Garth and Rietbrock, 2018). The expression of crustal thickness $\left(T_{c}\right)$ is

$$
T_{c}=D_{m}-T_{s}-T_{w} .
$$

where, $D_{m}$ is the Moho depth, $T_{s}$ is the sediment thickness, and $T_{w}$ is the seawater depth offshore and topography onshore. The remaining unknown quantity is the Moho depth, which is the interface between the crust and mantle since there are opensourced sediment thickness, bathymetry and topography data (please check our section 3.3).

The Moho burial depth variations will be mapped via gravity inversion based on lithospheric density modeling and 
https://doi.org/10.5194/se-2019-179

Preprint. Discussion started: 4 December 2019

(c) Author(s) 2019. CC BY 4.0 License.

(c) (i)

120 seismic profile constraints. The free-air gravity anomaly mainly includes gravity effects of the following layers: seawater, sediment, crust and mantle. Therefore, to estimate the gravity anomaly caused by the Moho undulations $\left(g_{\text {moho }}\right)$, which is the basis for Moho gravity inversion, it is necessary to calculate the gravity anomaly caused by seawater $\left(g_{\text {seaWater }}\right)$, sediment

$\left(g_{\text {sediment }}\right)$, crust $\left(g_{\text {crust }}\right)$ and mantle $\left(g_{\text {mantle }}\right)$ :

$$
g_{\text {moho }}=g_{\text {freeAir }}-\left(g_{\text {seaWater }}+g_{\text {sediment }}+g_{\text {crust }}\right)-g_{\text {mantle }}
$$

The gravity effect of each layer is determined by the density variations. Density modeling is a key issue for the Moho inversion. The seawater density is set to be a constant of $1.03 \mathrm{~g} \mathrm{~cm}^{-3}$ (Edgcomb and Bernhard, 2013; Bai et al., 2014; Amos et al., 2003); the sediment density is modeled and estimated based on the porosity and sediment depth (Sawyer, 1985; Bai et al., 2014). The mantle density variations can be converted from the seismic wave structures by the velocity-density relationship (Isaak et al., 1989; Bai et al., 2019a). The island arc crust can be divided into three layers: upper, middle and lower crusts. In

130 this study, according to seismic-wave velocities and our gravity simulation tests, the crustal density of the upper island arc is set to $2.68 \mathrm{~g} \mathrm{~cm}^{-3}$ (Kay and Kay, 1985; Qian and Wieczorek, 2012), the middle island arc (depth between $7 \mathrm{~km}$ and $22 \mathrm{~km}$ ) is set to $2.93 \mathrm{~g} \mathrm{~cm}^{-3}$ (Kay, 1978; Bai et al., 2013; Calvert, 2011), and the lower island arc is set to $3.18 \mathrm{~g} \mathrm{~cm}^{-3}$ (Kay, 1978; Nirrengarten et al., 2014). The density of normal oceanic crust is set to be a constant of $2.93 \mathrm{~g} \mathrm{~cm}^{-3}$, which is the same as that of the middle crust (White et al., 1992; Tetreault and Buiter, 2014). The density of the mantle without thermal perturbations

135 is set to $3.30 \mathrm{~g} \mathrm{~cm}^{-3}$ (Wang, 1970; Ranero and Sallares, 2004). After obtaining the gravity anomalies caused by the Moho undulations, the Moho burial depths are estimated using the gravity inversion method in the frequency domain constrained by the seismic profiles (Oldenburg, 1974; Parker, 2010).

\subsection{Defining Arc Boundaries and Magmatism Lifespan}

The island arc boundaries distinguish the Aleutian arc from the surrounding plates. The eastern parts of the Aleutian arc

140 magmas are accreted on continental crust (Reymer and Schubert, 1984; Jicha et al., 2006), and the western and central parts of the Aleutian arc magmas are accreted on oceanic crust. The primitive continental crustal thickness varies greatly, but the oceanic crustal thickness is more uniform (Reymer and Schubert, 1984; Jicha et al., 2006). Therefore, the eastern boundary of 
https://doi.org/10.5194/se-2019-179

Preprint. Discussion started: 4 December 2019

(c) Author(s) 2019. CC BY 4.0 License.

(c) (i)

our rate-estimating area is defined as the Unimak Volcano (Fig. 1), since it is a transitional region between the oceanic-oceanic subduction and the oceanic-continental subduction (Calvert, 2011). The southern and western boundaries are the Aleutian

145 Trench and the junction of the Aleutian Trench and the Kuril-Kamchatka Trench, respectively (Fig. 3).

The northern boundary is defined differently at the two sides of $173^{\circ} \mathrm{E}$. East of $173^{\circ} \mathrm{E}$, arc magmatism driven by dehydration is shallower than $150 \mathrm{~km}$ (Ruppert et al., 2007; Jacob et al., 1977; Davies and House, 1979; Ferris et al., 2003; Rasmussen et al., 2018). Therefore, the northern border is set to be the $150 \mathrm{~km}$ contour of the slab depth. However, west of $173^{\circ} \mathrm{E}$, there is a lack of slab subduction with a depth greater than $100 \mathrm{~km}$ due to the slab window here (Levin et al., 2005).

150 The BFZ can be set as the northern border (Jonathan M. Lees et al., 2000; Lay et al., 2017; Davaille and Lees, 2004).

According to the latest $40 \mathrm{Ar} / 39 \mathrm{Ar}$ dating and the existing K-Ar age, the Aleutian arc volcanic activity began in the Eocene Epoch, at approximately $46 \mathrm{Ma}$ (Jicha et al., 2006; Jicha and Jagoutz, 2015). The Aleutian island arc is an active area of seismicity today. Therefore, the magmatic activity lifespan is $46 \mathrm{Myr}$.

\subsection{Data Sets}

The free-air gravity anomalies, seafloor topography, sediment thickness, initial Moho geometry, oceanic crust age, deep seismic profiles, slab depth and dip are necessary for our magma production rate estimation. The 1 arcmin-resolution global relief model of the Earth's surface (ETOPO1) (Amante and Eakins, 2009), the 5 arcmin-resolution of the Total Sediment Thickness of the World's Oceans and Marginal Seas (Straume et al., 2019), the 1 arcmin-resolution global free-air gravity anomalies (Sandwell et al., 2014), and the 2 arcmin-resolution global oceanic lithospheric age data (Müller et al., 2008) are taken as our input. The three seismic profiles collected in the Aleutian region are the arc strike profile BB' and the two arc crossing profiles AA' and CC' (Lizarralde, 2002; Fliedner and Klemperer, 1999; Steven Holbrook et al., 1999) (Fig. 1).

\section{Results}

Along a series of integral trails perpendicular to the island arc strike, the first overview map of the magma production rate along the Aleutian arc is shown in Fig. 4, which is based on the crustal thickness mapped in Fig. 3. The magma production 165 rates are between $37 \mathrm{~km}^{3} \mathrm{~km}^{-1} \mathrm{Myr}^{-1}$ and $89 \mathrm{~km}^{3} \mathrm{~km}^{-1} \mathrm{Myr}^{-1}$ for the whole island arc, with an average of $61 \mathrm{~km}^{3} \mathrm{~km}^{-1} \mathrm{Myr}^{-1}$ 
https://doi.org/10.5194/se-2019-179

Preprint. Discussion started: 4 December 2019

(c) Author(s) 2019. CC BY 4.0 License.

(c) (i)

(Fig. 4b). There is a great rate difference between the eastern and western sides of $173^{\circ} \mathrm{E}$. West of $173^{\circ} \mathrm{E}$, where a slab window is located, the average rate is $41 \mathrm{~km}^{3} \mathrm{~km}^{-1} \mathrm{Myr}^{-1}$. East of $173^{\circ} \mathrm{E}$, the average rate is $67 \mathrm{~km}^{3} \mathrm{~km}^{-1} \mathrm{Myr}^{-1}$. There are three peaks on the whole Aleutian island arc (Fig. 4b). Peak A corresponds to the intersection between the Emperor Seamounts and the Aleutian Trench; this position is in the slab window. Between the Rat and Amlia fracture zones, the island arc magma production rate decreases from $70 \mathrm{~km}^{3} \mathrm{~km}^{-1} \mathrm{Myr}^{-1}$ to $53 \mathrm{~km}^{3} \mathrm{~km}^{-1} \mathrm{Myr}^{-1}$ and then increases to $83 \mathrm{~km}^{3} \mathrm{~km}^{-1} \mathrm{Myr}^{-1}$ from west to east. Peak B corresponds to the Rat Fracture Zone, and peak C corresponds to the Amlia Fracture Zone. Overall, the magma production rate coincides with the slab dip, mainly increasing from west to east (Fig. 4b). The correlation coefficient between the rates and dips is 0.83 , so the rates are very sensitive to the dip variation. Magma production rates along the Izu-BoninMariana subduction system also show a close correlation between the magma production rates and slab dips (Bai, et al., 175 submitted to EPSL).

The rate uncertainties are mainly due to the accreted crustal thickness, arc boundaries and magmatic activity lifespan. Figure 5 compares the Moho depths via the seismic interpretation and gravity inversion along the three seismic profiles. The two results have similar long-wavelength trends, and the root mean square (RMS) between them is $2.8 \mathrm{~km}$. The differences are from the uncertainties or error of the gravity modeling and seismic measurements, data processing, interpretations and so

180 on.

To estimate the uncertainties of the rate variations in this paper, a comparison is made with the previous results. However, the previous estimations are based on different magmatic activity lifespans. After setting the magmatic activity lifespan as 46 Myr, the former results were $54 \mathrm{~km}^{3} \mathrm{~km}^{-1} \mathrm{Myr}^{-1}$ (Reymer and Schubert, 1984), $59 \mathrm{~km}^{3} \mathrm{~km}^{-1} \mathrm{Myr}^{-1}$ (Crisp, 1984), $89 \mathrm{~km}^{3} \mathrm{~km}^{-1}$ $\mathrm{Myr}^{-1}$ (Steven Holbrook et al., 1999), $81 \mathrm{~km}^{3} \mathrm{~km}^{-1} \mathrm{Myr}^{-1}$ (Lizarralde, 2002), $72 \mathrm{~km}^{3} \mathrm{~km}^{-1} \mathrm{Myr}^{-1}$ (Dimalanta et al., 2002), and

$18589 \mathrm{~km}^{3} \mathrm{~km}^{-1} \mathrm{Myr}^{-1}$ (Jicha et al., 2006; Jicha and Jagoutz, 2015). All previous values are in the range of our rate estimations $\left(37-89 \mathrm{~km}^{3} \mathrm{~km}^{-1} \mathrm{Myr}^{-1}\right)$. This demonstrates that our estimation results are consistent with those results of our predecessors in general. However, the rates given in this paper are a variety of values.

\section{Discussion}

The rate estimation results suggest that slab dip, fracture zone, and ridge subduction are potential factors affecting island 
https://doi.org/10.5194/se-2019-179

Preprint. Discussion started: 4 December 2019

(c) Author(s) 2019. CC BY 4.0 License.

(c) (i)

190 arc magmatism. Therefore, the specific mechanism influencing the island arc magma production rates are discussed mainly from the former three aspects.

\subsection{Influence of Slab Dip Variations on Arc Magma Production Rate}

Fluid released from slab dehydration is one of the main driving factors of arc magmatism (Turner et al., 2000; Grove et al., 2012). The dehydration is mainly controlled by the slab thermal structures(Schmidt and Poli, 1998), which vary with the subducted slab depths, so fluid flux also varies with the depth (Zheng et al., 2016). Figure 6 shows the water flux variations according to the burial depths. Approximately $90 \%$ of the water from the slab is released at depths between $60-80 \mathrm{~km}$ under the forearc region (Ribeiro et al., 2015; Tatsumi and Kogiso, 1997; Kerrick and Connolly, 1998; Schmidt and Poli, 1998; Gorman et al., 2006). The water released at this depth has no contribution to the formation of the island arc magma that is restricted by temperature here (Tatsumi and Kogiso, 1997; Schmidt and Poli, 1998; Ribeiro et al., 2015). Most of the remaining $10 \%$ of the water is released under the island arc with depths from $80-150 \mathrm{~km}$, which can induce melting of the mantle wedge due to the suitable temperature here (Schmidt and Poli, 1998; Ribeiro et al., 2015; Zheng et al., 2016).

Figure 6 also shows the difference in the water flux for the different slab dips: subarc water flux of high dip subduction is slightly greater than that of the low dip subduction (Gorman et al., 2006; van Keken et al., 2011; Zheng et al., 2016). Note that even though the water flux released under the island arc region is limited and the water flux difference is small between the low-dip and high-dip subduction, the mantle wedge melting degree will increase by $10 \%$ by adding a $0.2 \%$ supply of water (Stolper and Newman, 1994; Pearce and Peate, 1995; Stern, 2002). The melting differences at the mantle wedge will result in different arc magma volumes and variable arc magma production rates (Fig. 7).

\subsection{Influence of Fracture Zone Subduction on Arc Magma Production Rate}

The highly fractured oceanic crust and upper mantle exposes a large amount of peridotite to the fracture surface, and the main elements of peridotite are $\mathrm{Fe}^{2+}, \mathrm{Mg}^{2+}$ and $\mathrm{Si}^{4+}$ (Singer et al., 2013; Manea et al., 2014; Singer et al., 2007; Wehrmann et al., 2014). The subducting Pacific Plate carries a large amount of matter dissolved in seawater such as $\mathrm{Na}^{+}, \mathrm{K}^{+}$, and $\mathrm{Cl}^{-}(\mathrm{Parendo}$ et al., 2017). The intense material exchange between peridotite and the soluble matter with different elemental compositions 
https://doi.org/10.5194/se-2019-179

Preprint. Discussion started: 4 December 2019

(c) Author(s) 2019. CC BY 4.0 License.

(c) (i)

is called hydrothermal alteration (Stefánsson and Kleine, 2017; Parendo et al., 2017; Kitajima et al., 2010). The intense hydrothermal alteration transforms peridotite into serpentinite on or near the surface of the subducted slab (Singer et al., 2013;

215 Weller and Stern, 2018; Manea et al., 2014; Schlaphorst et al., 2016).

When the water-rich (13 wt \%) and light peridotite rises to a depth of 80-120 km, it will decompose due to decompression (Zheng et al., 2016). Therefore, the fluids produced by the fractured slab are more than those released by the normal slab dehydration (Singer et al., 2013; Weller and Stern, 2018; Manea et al., 2014; Wehrmann et al., 2014; Singer et al., 2007; Schlaphorst et al., 2016). More fluids flow into the mantle wedge and promote more mantle wedge melting (Fig. 8) (Ulmer and Trommsdorff, 1995; Scambelluri et al., 2001; Hacker et al., 2003), which increases the island arc magma production rate.

\subsection{Influence of Ridge Subduction on Arc Magma Production Rate}

Geochemical evidence shows that there are obvious elemental differences between adakites west of $173^{\circ} \mathrm{E}$ and basalts east of $173^{\circ} \mathrm{E}$ (Defant and Drummond, 1990; Yogodzinski et al., 2001; Levin et al., 2005). The rock difference is due to the two ways of island arc magmatism: the molten mantle wedge is induced by fluids east of $173^{\circ} \mathrm{E}$ and by slab melts west of

$225173^{\circ} \mathrm{E}$. The slab window west of $173^{\circ} \mathrm{E}$ exposes the edge of the subducted Pacific Plate to the mantle (Davaille and Lees, 2004; Lay et al., 2017; Lees et al., 2007). As shown in Fig. 8, at the edge of the slab window, the hot asthenosphere mantle upwells and provides a high enough temperature for slab melting. High-Si products emerged after melting of the subducted slab dominated by basalt oceanic crust (Kay, 1978; Cai et al., 2014; Yogodzinski et al., 2013). The melting of the mantle wedge is induced by the melting products of the subducted slab (Yogodzinski et al., 2013; Pineda-Velasco et al., 2018; Rosenbaum et al., 2018), resulting in island arc magma.

At peak A, the subducted slab strength is weak due to the high thermal structure of the seamount located slab (Morell, 2016; Davaille and Lees, 2004; Nishizawa et al., 2017). When the edge of the slab window is at a high temperature, the weak slab will rupture (LisMancilla et al., 2015; De Boorder et al., 1998). Therefore, the lithospheric mantle and lower crust subside into the asthenosphere (Kay and Kay, 1993; LisMancilla et al., 2015; Gögüs et al., 2017). The high temperature and low density materials in the asthenosphere upwell again, which promotes greater melting of the subducted slab (Lee and King, 2010; Levin et al., 2005; Contreras-Reyes et al., 2008). Therefore, due to ridge subduction, more melting products interact with the mantle 
https://doi.org/10.5194/se-2019-179

Preprint. Discussion started: 4 December 2019

(c) Author(s) 2019. CC BY 4.0 License.

(c) (i)

wedge and induce more magma upwelling, which finally increases the island arc magma production rate.

\section{Conclusions}

Estimating island arc magma production rates requires arc magmatic thickness, arc boundaries and magmatism lifespan.

240 Magmatic thickness is mapped via gravity inversion, which is constrained by deep seismic profiles. The boundaries of the intra-oceanic subduction part of the Aleutian arc are delineated according to the tectonic settings. The newest geochemical dating indicates that the subduction initiated at $46 \mathrm{Ma}$. Finally, the first overview of the island arc magma production rate variations along the Aleutian arc is mapped.

The magma production rate variations along the Aleutian arc indicate that there are mainly three factors affecting the island arc magma production rate: slab dip, fracture zone, and ridge subduction. The formation of island arcs is mainly due to the melting of the mantle wedge, which is driven by the fluids and melts from the subducted slabs at the east and west sides of $173^{\circ} \mathrm{E}$ of the Aleutian arc.

The fluid-driven mechanisms of magmatism are as follows: (1) The slab water flux at subarc depths increases with increasing slab dip, and the mantle wedge melting degree will increase by $10 \%$ when adding $0.2 \%$ water supply. Therefore, the island arc magma production rates have the same trend as the slab dips. (2) The new water-rich and light serpentine is formed in the fracture zones by the material exchange due to the elemental difference between the soluble matter of the subducted slab and the peridotite exposed on the fracture zones, and it decomposes under the island arc due to decompression. Therefore, both the slab fluid flux and mantle wedge melting degree are increased where the fracture zone is subducting, and subsequently, the fracture zones correspond to peaks in the arc magma production rate.

The influence mechanism of the melt-driven factor is as follows: The slab located in the Emperor Seamounts is weak and more easily molten. Therefore, more slab melts are produced, the melting degree of the mantle wedge increases and more island arc magmas are produced. Therefore, the ridge subduction at the slab window also corresponds to the arc magma production rate peak.

Data availability. The datasets used for this research are all recorded in the article, please check section 3.3. 
https://doi.org/10.5194/se-2019-179

Preprint. Discussion started: 4 December 2019

(c) Author(s) 2019. CC BY 4.0 License.

(c) (i)

Author contributions. Bai proposed the idea of this study and wrote the article. Zhang and Dong collated the basic datasets of the research and wrote the code. Everyone participated in the final mechanism discussion, checked and modified the article.

Competing interests. The authors declare that they have no conflict of interest.

Acknowledgements. Thanks for the financial support provided by National Natural Science Foundation of China (Grant No. 41976051, U170120019), the Key National Research Project of China (Grant No. 2018YFC0603300), the Fundamental

Research Funds for the Central Universities China (Grant No. 17CX02003A), and the Open Fund of State Key Laboratory of Earthquake Dynamics (Grant No. LED2019B01).

\section{References}

Amante, C., and Eakins, B. W.: ETOPO1 arc-minute global relief model: procedures, data sources and analysis, NOAA Technical Memorandum, 2009.

270 Amos, C. L., Jones, T. E. R., and Chaplin, J.: The Manifestation of Fluid-Transmitted Bed Shear Stress in a Smooth Annular Flume-a Comparison of Methods, Journal of Coastal Research, 19, 1094-1103, https://www.jstor.org/stable/4299251, 2003.

Andrys, J., Kelley, K. A., Cottrell, E., and Coombs, M. L.: Volatile contents of western Aleutian magmas and their relationship to slab thermal structure, AGU Fall Meeting Abstracts, 2018.

Bai, Y., Williams, S. E., Müller, R. D., Zhan, L., and Hosseinpour, M.: Mapping crustal thickness using marine gravity data: 275 Methods and uncertainties, Geophysics, 79, F1-F10, https://doi.org/10.1190/geo2013-0270.1, 2014.

Bai, Y., Gui, Z., Li, M., Dong, D., Wu, S., and Wang, Z.: Crustal thickness over the NW Pacific and its tectonic implications, Journal of Asian Earth Sciences, 185, 104050, https://doi.org/10.1016/j.jseaes.2019.104050, 2019a.

Bai, Y., Li, M., Wu, S., Dong, D., Gui, Z., Sheng, J., and Wang, Z.: Upper mantle density modelling for large-scale Moho gravity inversion: case study on the Atlantic Ocean, Geophysical Journal International, 216, 2134-2147, 280 https://doi.org/10.1093/gji/ggz003, 2019b.

Bai, Z., Zhang, S., and Braitenberg, C.: Crustal density structure from 3D gravity modeling beneath Himalaya and Lhasa 
https://doi.org/10.5194/se-2019-179

Preprint. Discussion started: 4 December 2019

(c) Author(s) 2019. CC BY 4.0 License.

(c) (i)

blocks, Tibet, Journal of Asian Earth Sciences, 78, 301-317, https://doi.org/10.1016/j.jseaes.2012.12.035, 2013.

Cai, Y., LaGatta, A., Goldstein, S. L., Langmuir, C. H., Gómez-Tuena, A., Martín-del Pozzo, A. L., and Carrasco-Núñez, G.: Hafnium isotope evidence for slab melt contributions in the Central Mexican Volcanic Belt and implications for slab melting

in hot and cold slab arcs, Chemical Geology, 377, 45-55, https://doi.org/10.1016/j.chemgeo.2014.04.002, 2014.

Calvert, A. J.: The Seismic Structure of Island Arc Crust, in: Arc-Continent Collision, Frontiers in Earth Sciences, 87-119, 2011.

Chekhovich, V. D., Sheremet, O. G., and Kononov, M. V.: Strike-slip fault system in the Earth's crust of the Bering Sea: A relic of boundary between the Eurasian and North American lithospheric plates, Geotectonics, 48, 255-272, https://doi.org/10.1134/s0016852114040037, 2014.

Clift, P.: Controls on tectonic accretion versus erosion in subduction zones: Implications for the origin and recycling of the continental crust, Reviews of Geophysics, 42, https://doi.org/10.1029/2003RG000127, 2004.

Contreras-Reyes, E., Grevemeyer, I., Flueh, E. R., and Reichert, C.: Upper lithospheric structure of the subduction zone offshore of southern Arauco peninsula, Chile, at $\sim 38^{\circ} \mathrm{S}$, Journal of Geophysical Research, 113, https://doi.org/10.1029/2007JB005569, 2008.

Crisp, J. A.: Rates of magma emplacement and volcanic output, Journal of Volcanology Geothermal Research, 20, 177-211, https://doi.org/10.1016/0377-0273(84)90039-8, 1984.

Cross, R. S., and Freymueller, J. T.: Evidence for and implications of a Bering plate based on geodetic measurements from the Aleutians and western Alaska, Journal of Geophysical Research, 113, https://doi.org/10.1029/2007JB005136, 2008.

Davaille, A., and Lees, J. M.: Thermal modeling of subducted plates: tear and hotspot at the Kamchatka corner, Earth Planetary Science Letters, 226, 293-304, https://doi.org/10.1016/j.epsl.2004.07.024, 2004.

Davies, J. N., and House, L.: Aleutian subduction zone seismicity, volcano-trench separation, and their relation to great thrusttype earthquakes, Journal of Geophysical Research, 84, https://doi.org/10.1029/JB084iB09p04583, 1979.

De Boorder, H., Spakman, W., White, S., and Wortel, M.: Late Cenozoic mineralization, orogenic collapse and slab detachment 305 in the European Alpine Belt, Earth Planetary Science Letters, 164, 569-575, https://doi.org/10.1016/S0012-821X(98)00247-7, 1998. 
https://doi.org/10.5194/se-2019-179

Preprint. Discussion started: 4 December 2019

(c) Author(s) 2019. CC BY 4.0 License.

(c) (i)

Defant, M. J., and Drummond, M. S.: Derivation of some modern arc magmas by melting of young subducted lithosphere, Nature, 347, 662-665, https://doi.org/10.1038/347662a0, 1990.

DeMets, C., Gordon, R. G., and Argus, D. F.: Geologically current plate motions, Geophysical Journal International, 181, 1 -

Dimalanta, C., Taira, A., Yumul Jr, G., Tokuyama, H., Mochizuki, K. J. E., and Letters, P. S.: New rates of western Pacific island arc magmatism from seismic and gravity data, Earth and Planetary Science Letters, 202, 105-115, https://doi.org/10.1016/S0012-821X(02)00761-6, 2002.

Edgcomb, V. P., and Bernhard, J. M.: Heterotrophic protists in hypersaline microbial mats and deep hypersaline basin water

columns, Life, 3, 346, https://doi.org/10.3390/life3020346, 2013.

Ferris, A., Abers, G. A., Christensen, D. H., and Veenstra, E.: High resolution image of the subducted Pacific (?) plate beneath central Alaska, 50-150 km depth, Earth and Planetary Science Letters, 214, 575-588, https://doi.org/10.1016/S0012$821 \mathrm{X}(03) 00403-5,2003$.

Fliedner, M. M., and Klemperer, S. L.: Structure of an island-arc: Wide-angle seismic studies in the eastern Aleutian Islands,

320 Alaska, Journal of Geophysical Research: Solid Earth, 104, 10667-10694, https://doi.org/10.1029/98JB01499, 1999.

Garth, T., and Rietbrock, A.: Downdip velocity changes in subducted oceanic crust beneath Northern Japan-insights from guided waves, Geophysical Journal International, 198, 1342-1358, https://doi.org/10.1093/gji/ggu206, 2018.

Geist, E. L., Childs, J. R., and Scholl, D. W.: The origin of summit basins of the Aleutian Ridge: Implications for block rotation of an arc massif, Tectonics, 7, 327-341, https://doi.org/10.1029/TC007i002p00327, 1988.

325 Gögüs, O. H., Ueda, K., and Gerya, T.: Magmatism in Lithosphere Delamination process inferred from numerical models, EGU General Assembly Conference Abstracts, 2017, 12321,

Gorman, P. J., Kerrick, D. M., and Connolly, J. A. D.: Modeling open system metamorphic decarbonation of subducting slabs, Geochemistry, Geophysics, Geosystems, 7, https://doi.org/10.1029/2005GC001125, 2006.

Grove, T., Chatterjee, N., Parman, S., and Medard, E.: The influence of H2O on mantle wedge melting, Earth and Planetary 330 Science Letters, 249, 74-89, https://doi.org/10.1016/j.epsl.2006.06.043, 2006.

Grove, T. L., Till, C. B., and Krawczynski, M. J.: The Role of H2O in Subduction Zone Magmatism, Annual Review of Earth 
https://doi.org/10.5194/se-2019-179

Preprint. Discussion started: 4 December 2019

(c) Author(s) 2019. CC BY 4.0 License.

(c) (i)

and Planetary Sciences, 40, 413-439, https://doi.org/10.1146/annurev-earth-042711-105310, 2012.

Hacker, B. R., Peacock, S. M., Abers, G. A., and Holloway, S. D.: Subduction factory 2. Are intermediate-depth earthquakes

in subducting slabs linked to metamorphic dehydration reactions?, Journal of Geophysical Research, 108, 2030,

https://doi.org/10.1029/2001JB001129, 2003.

Hayes, G. P., Moore, G. L., Portner, D. E., Hearne, M., Flamme, H., Furtney, M., and Smoczyk, G. M.: Slab2, a comprehensive subduction zone geometry model, Science, eaat4723, https://doi.org/10.1126/science.aat4723, 2018.

Isaak, D. G., Anderson, O. L., Goto, T., and Suzuki, I.: Elasticity of single-crystal forsterite measured to 1700 K, Journal of Geophysical Research: Solid Earth, 94, https://doi.org/10.1029/JB094iB05p05895, 1989.

340 Jacob, K. H., Nakamura, K., and Davies, J. N.: Trench-volcano gap along the Alaska-Aleutian arc: facts, and speculations on the role of terrigenous sediments for subduction, in: Island arcs, deep sea trenches and back-arc basins, Maurice Ewing Series I, Amer. Geophys. Union, 243, 1977.

Jicha, B. R., Scholl, D. W., Singer, B. S., Yogodzinski, G. M., and Kay, S. M.: Revised age of Aleutian Island Arc formation implies high rate of magma production, Geology, 34, https://doi.org/10.1130/G22433.1, 2006.

345 Jicha, B. R., Singer, B. S., Kay, S. M., and Scholl, D. W.: The Timing of Aleutian Arc Inception and Nascent Magmatic Evolution: Current Status and Future Prospects, 2011.

Jicha, B. R., and Jagoutz, O.: Magma Production Rates for Intraoceanic Arcs, Elements, 11, 105-111, https://doi.org/10.2113/gselements.11.2.105, 2015.

Jonathan M. Lees, Mark Brandon, and Park, J.: Kamchatka: Edge of the Plate, IRIS Newsletter, 2000, 17-19, 2000.

350 Kay, R.: Aleutian magnesian andesites: melts from subducted Pacific Ocean crust, Journal of Volcanology Geothermal Research, 4, 117-132, https://doi.org/10.1016/0377-0273(78)90032-X, 1978.

Kay, R. W., and Kay, S. M.: Delamination and delamination magmatism, Tectonophysics, 219, 177-189, https://doi.org/10.1016/0040-1951(93)90295-U, 1993.

Kay, S. M., and Kay, R.: Role of crystal cumulates and the oceanic crust in the formation of the lower crust of the Aleutian arc,

Geology, 13, 461-464, https://doi.org/10.1130/0091-7613(1985)13<461:ROCCAT>2.0.CO;2, 1985.

Kerrick, D. M., and Connolly, J. A. D.: Subduction of ophicarbonates and recycling of CO2 and H2O, Geology, 26, 375, 
https://doi.org/10.5194/se-2019-179

Preprint. Discussion started: 4 December 2019

(c) Author(s) 2019. CC BY 4.0 License.

(c) (1)

https://doi.org/10.1130/0091-7613(1998)026<0375:SOOARO>2.3.CO;2, 1998.

Kitajima, K., Maruyama, S., Utsunomiya, S., and Liou, J. G.: Seafloor Hydrothermal Alteration at an Archaean Mid-Ocean Ridge, Journal of Metamorphic Geology, 19, 583-599, https://doi.org/10.1046/j.0263-4929.2001.00330.x, 2010.

Kogan, M. G., Frolov, D. I., Vasilenko, N. F., Freymueller, J. T., Steblov, G. M., Ekström, G., Titkov, N. N., and Prytkov, A. S.: Plate coupling and strain in the far western Aleutian arc modeled from GPS data, Geophysical Research Letters, 44, 31763183, https://doi.org/10.1002/2017GL072735, 2017.

Lay, T., Ye, L., Bai, Y., Cheung, K. F., Kanamori, H., Freymueller, J., Steblov, G. M., and Kogan, M. G.: Rupture along 400 $\mathrm{km}$ of the Bering fracture zone in the Komandorsky Islands earthquake (MW 7.8) of 17 July 2017, Geophysical Research Letters, 44, 12,161-112,169, https://doi.org/10.1002/2017GL076148, 2017.

Lee, C., and King, S. D.: Why are high-Mg\# andesites widespread in the western Aleutians? A numerical model approach, Geology, 38, 583-586, https://doi.org/10.1130/G30714.1, 2010.

Lees, J. M., VanDecar, J., Gordeev, E., and Ozerov, A. Y.: Three dimensional images of the Kamchatka-Pacific plate cusp, https://doi.org/10.1029/172GM06, 2007.

370 Levin, V., Shapiro, N. M., Park, J., and Ritzwoller, M. H.: Slab portal beneath the western Aleutians, Geology, 33, https://doi.org/10.1130/G20863.1, 2005.

LEWIS, S. D., LADD, J. W., and BRUNS, T. R.: Structural development of an accretionary prism by thrust and strike-slip faulting: Shumagin region, Aleutian Trench, Geological Society of America Bulletin, 100, 767-782, https://doi.org/10.1130/0016-7606(1988)100<0767:SDOAAP>2.3.CO;2, 1988.

375 LisMancilla, F. d., Booth-Rea, G., Stich, D., Pérez-Peña, J. V., Morales, J., Azañón, J. M., Martin, R., and Giaconia, F.: Slab rupture and delamination under the Betics and Rif constrained from receiver functions, Tectonophysics, 663, 225-237, https://doi.org/10.1016/j.tecto.2015.06.028, 2015.

Liu, Y., Gao, S., Lee, C., Hu, S., Liu, X., and Yuan, H.: Melt-peridotite interactions: Links between garnet pyroxenite and high-Mg\# signature of continental crust, Earth and Planetary Science Letters, 234, 39-57, 380 https://doi.org/10.1016/j.epsl.2005.02.034, 2005.

Liu, Z., Jianghai, L. I., Cui, X., Yun, X., and Fan, Q.: Geometry of Aleutian Subduction Zone and Its Kinematic Genesis, 
https://doi.org/10.5194/se-2019-179

Preprint. Discussion started: 4 December 2019

(c) Author(s) 2019. CC BY 4.0 License.

(c) (i)

Geological Review, https://doi.org/10.16509/j.georeview.2018.03.002, 2018.

Lizarralde, D.: Crustal construction of a volcanic arc, wide-angle seismic results from the western Alaska Peninsula, Journal of Geophysical Research, 107, https://doi.org/10.1029/2001JB000230, 2002.

Manea, V. C., Leeman, W. P., Gerya, T., Manea, M., and Zhu, G.: Subduction of fracture zones controls mantle melting and geochemical signature above slabs, Nat Commun, 5, 5095, https://doi.org/10.1038/ncomms6095, 2014.

Morell, K. D.: Seamount, ridge, and transform subduction in southern Central America, Tectonics, 35, 357-385, https://doi.org/10.1002/2015TC003950, 2016.

Müller, R. D., Sdrolias, M., Gaina, C., and Roest, W. R.: Age, spreading rates, and spreading asymmetry of the world's ocean

crust, Geochemistry, Geophysics, Geosystems, 9, https://doi.org/10.1029/2007GC001743, 2008.

Nirrengarten, M., Gernigon, L., and Manatschal, G.: Lower crustal bodies in the Møre volcanic rifted margin: Geophysical determination and geological implications, Tectonophysics, 636, 143-157, https://doi.org/10.1016/j.tecto.2014.08.004, 2014.

Nishizawa, T., Nakamura, H., Churikova, T., Gordeychik, B., Ishizuka, O., Haraguchi, S., Miyazaki, T., Vaglarov, B. S., Chang, Q., Hamada, M., Kimura, J. I., Ueki, K., Toyama, C., Nakao, A., and Iwamori, H.: Genesis of ultra-high-Ni olivine in high$395 \mathrm{Mg}$ andesite lava triggered by seamount subduction, Sci Rep, 7, 11515, https://doi.org/10.1038/s41598-017-10276-3, 2017. Oldenburg, D. W.: The inversion and interpretation of gravity anomalies, Geophysics, 39, 526-536, https://doi.org/10.1190/1.1440444, 1974.

Parendo, C. A., Jacobsen, S. B., and Wang, K.: K isotopes as a tracer of seafloor hydrothermal alteration, Proc Natl Acad Sci U S A, 114, 1827-1831, https://doi.org/10.1073/pnas.1609228114, 2017.

400 Parker, R. L.: The Rapid Calculation of Potential Anomalies, Geophysical Journal International, 31, 447-455, https://doi.org/10.1111/j.1365-246X.1973.tb06513.x, 2010.

Pearce, J. A., and Peate, D. W.: Tectonic implications of the composition of volcanic arc magmas, Annual review of Earth planetary sciences, 23, 251-285, https://doi.org/10.1146/annurev.ea.23.050195.001343, 1995.

Pineda-Velasco, I., Kitagawa, H., Nguyen, T. T., Kobayashi, K., and Nakamura, E.: Production of High-Sr Andesite and Dacite 405 Magmas by Melting of Subducting Oceanic Lithosphere at Propagating Slab Tears, Journal of Geophysical Research: Solid Earth, 123, 3698-3728, https://doi.org/10.1029/2017JB015066, 2018. 
https://doi.org/10.5194/se-2019-179

Preprint. Discussion started: 4 December 2019

(c) Author(s) 2019. CC BY 4.0 License.

(c) (i)

Qian, H., and Wieczorek, M. A.: Density and porosity of the lunar crust from gravity and topography, Journal of Geophysical Research Planets, 117, https://doi.org/10.1029/2012JE004062, 2012.

Ranero, C. R., and Sallares, V.: Geophysical evidence for hydration of the crust and mantle of the Nazca plate during bending 410 at the north Chile trench, Geology, 32, 549-552, https://doi.org/10.1130/G20379.1, 2004.

Rasmussen, D., Plank, T., Roman, D., Hauri, E., Janiszewski, H., Lev, E., Nicolaysen, K., and Izbekov, P.: How Slab Depth is Reflected in Aleutian Arc Magmas, AGU Fall Meeting Abstracts, 2018,

Reymer, A., and Schubert, G.: Phanerozoic Addition Rates to the Continental Crust and Crustal Growth, Tectonics, 3, 63-77, https://doi.org/10.1029/TC003i001p00063, 1984.

415 Ribeiro, J. M., Stern, R. J., Kelley, K. A., Shaw, A. M., Martinez, F., and Ohara, Y.: Composition of the slab-derived fluids released beneath the Mariana forearc: Evidence for shallow dehydration of the subducting plate, Earth and Planetary Science Letters, 418, 136-148, https://doi.org/10.1016/j.epsl.2015.02.018, 2015.

Rollinson, H.: Secular evolution of the continental crust: Implications for crust evolution models, Geochemistry Geophysics Geosystems, 9, https://doi.org/10.1029/2008GC002262, 2008.

420 Rosenbaum, G., Sandiford, M., Caulfield, J., and Garrison, J. M.: A trapdoor mechanism for slab tearing and melt generation in the northern Andes, Geology, 47, 23-26, https://doi.org/10.1130/g45429.1, 2018.

Rudnick, R. L., and Fountain, D. M.: Nature and composition of the continental crust: a lower crustal perspective, Reviews of Geophysics, 33(3), 267, https://doi.org/10.1029/95RG01302, 1995.

Ruppert, N. A., Lees, J. M., and Kozyreva, N. P.: Seismicity, earthquakes and structure along the Alaska-Aleutian and

Kamchatka-Kurile Subduction Zones: A review, in: Volcanism and Subduction: The Kamchatka Region, Geophysical Monograph Series, 129-144, 2007.

Sandwell, D. T., Muller, R. D., Smith, W. H. F., Garcia, E., and Francis, R.: New global marine gravity model from CryoSat2 and Jason-1 reveals buried tectonic structure, Science, 346, 65-67, https://doi.org/10.1126/science.1258213, 2014.

Sawyer, D. S.: Total tectonic subsidence: A parameter for distinguishing crust type at the U.S. Atlantic Continental Margin, 430 Journal of Geophysical Research Solid Earth, 90, 7751-7769, https://doi.org/10.1029/JB090iB09p07751, 1985.

Scambelluri, M., Philippot, P., Andersen, T., Frezzotti, M. L., and Burke, E. A. J.: Deep fluids in subduction zones, Lithos, 55, 
https://doi.org/10.5194/se-2019-179

Preprint. Discussion started: 4 December 2019

(c) Author(s) 2019. CC BY 4.0 License.

(c) (i)

213-227, https://doi.org/10.1016/S0024-4937(00)00046-3, 2001.

Schlaphorst, D., Kendall, J. M., Collier, J. S., Verdon, J. P., Blundy, J., Baptie, B., Latchman, J. L., Massin, F., and Bouin, M.P.: Water, oceanic fracture zones and the lubrication of subducting plate boundaries - insights from seismicity, Geophysical Journal International, 204, 1405-1420, https://doi.org/10.1093/gji/ggv509, 2016.

Schmidt, M. W., and Poli, S.: Experimentally based water budgets for dehydrating slabs and consequences for arc magma generation, Earth and Planetary Science Letters, 163, 361-379, https://doi.org/10.1016/S0012-821X(98)00142-3, 1998.

Scholl, D. W.: Viewing the tectonic evolution of the Kamchatka-Aleutian (KAT) connection with an Alaska crustal extrusion perspective, Washington DC American Geophysical Union Geophysical Monograph Series, 172, 3-35, 440 https://doi.org/10.1029/172GM03, 2007.

Sdrolias, M., and Müller, R. D.: Controls on back-arc basin formation, Geochemistry, Geophysics, Geosystems, 7, https://doi.org/10.1029/2005gc001090, 2006.

Sharp, W. D., and Clague, D. A.: 50-Ma Initiation of Hawaiian-Emperor Bend Records Major Change in Pacific Plate Motion, Science, 313, 1281-1284, https://doi.org/10.1126/science.1128489, 2006.

445 Singer, B. S., Jicha, B. R., Leeman, W. P., Rogers, N. W., Thirlwall, M. F., Ryan, J., and Nicolaysen, K. E.: Along-strike trace element and isotopic variation in Aleutian Island arc basalt: Subduction melts sediments and dehydrates serpentine, Journal of Geophysical Research, 112, https://doi.org/10.1029/2006JB004897, 2007.

Singer, B. S., Leeman, W. P., Thirlwall, M. F., and Rogers, N. W.: Does Fracture Zone Subduction Increase Sediment Flux and Mantle Melting in Subduction Zones? Trace Element Evidence from Aleutian Arc Basalt, 2013.

450 Stefánsson, A., and Kleine, B. I.: Hydrothermal Alteration, https://doi.org/10.1007/978-3-319-39193-9_65-1, 2017.

Stern, R. J.: Subduction zones, Reviews of Geophysics, 40, https://doi.org/10.1029/2001rg000108, 2002.

Steven Holbrook, W., Lizarralde, D., McGeary, S., Bangs, N., and Diebold, J.: Structure and composition of the Aleutian island arc and implications for continental crustal growth, Geology, 27, 31-34, https://doi.org/10.1130/00917613(1999)027\%3C0031:SACOTA\%3E2.3.CO;2, 1999.

455 Stolper, E., and Newman, S.: The role of water in the petrogenesis of Mariana trough magmas, Earth Planetary Science Letters, 121, 293-325, https://doi.org/10.1016/0012-821X(94)90074-4, 1994. 
https://doi.org/10.5194/se-2019-179

Preprint. Discussion started: 4 December 2019

(c) Author(s) 2019. CC BY 4.0 License.

(c) (i)

Straume, E. O., Gaina, C., Medvedev, S., Hochmuth, K., Gohl, K., Whittaker, J. M., Abdul Fattah, R., Doornenbal, J. C., and Hopper, J. R.: GlobSed: Updated Total Sediment Thickness in the World's Oceans, Geochemistry, Geophysics, Geosystems, 20, 1756-1772, https://doi.org/10.1029/2018gc008115, 2019.

460 Suo, Y., Li, S., Li, X., Guo, L., and Wang, Y.: Crustal thickness anomalies in the Indian Ocean inferred from gravity analysis, Geological Journal, 634-643, https://doi.org/10.1002/gj.2786, 2016.

Tatsumi, Y., and Kogiso, T.: Trace element transport during dehydration processes in the subducted oceanic crust: 2. Origin of chemical and physical characteristics in arc magmatism, Earth Planet.sci.lett, 148, 207-221, https://doi.org/10.1016/S0012821X(97)00019-8, 1997.

465 Taylor, S. R.: The origin and growth of continents, Tectonophysics, 4, 17-34, https://doi.org/10.1016/0040-1951(67)90056-X, 1967.

Tenzer, R., Chen, W., and Jin, S.: Effect of Upper Mantle Density Structure on Moho Geometry, Pure Applied Geophysics, 172, 1563-1583, https://doi.org/10.1007/s00024-014-0960-2, 2015.

Tetreault, J. L., and Buiter, S. J. H.: Future accreted terranes: a compilation of island arcs, oceanic plateaus, submarine ridges, seamounts, and continental fragments, Solid Earth, 5, 1243-1275, https://doi.org/10.5194/se-5-1243-2014, 2014.

Thorkelson, D. J.: Subduction of diverging plates and the principles of slab window formation, Tectonophysics, 255, 47-63, https://doi.org/10.1016/0040-1951(95)00106-9, 1996.

Tollan, P., and Hermann, J.: Arc magmas oxidised by water dissociation and hydrogen incorporation in orthopyroxene, Nat Geosci, 12, 667-671, https://doi.org/10.1038/s41561-019-0411-x, 2019.

475 Torsvik, T. H., Doubrovine, P. V., Steinberger, B., Gaina, C., Spakman, W., and Domeier, M.: Pacific plate motion change caused the Hawaiian-Emperor Bend, Nat Commun, 8, 15660, https://doi.org/10.1038/ncomms15660, 2017.

Turner, S. P., George, R. M. M., Evans, P. J., Hawkesworth, C. J., and Zellmer, G. F.: Time-Scales of Magma Formation, Ascent and Storage Beneath Subduction-Zone Volcanoes, Philosophical Transactions Mathematical Physical Engineering Sciences, 358, 1443-1464, https://doi.org/10.1098/rsta.2000.0598, 2000.

480 Ulmer, P., ., and Trommsdorff, V.: Serpentine stability to mantle depths and subduction-related magmatism, Science, 268, 858861, https://doi.org/10.1126/science.268.5212.858, 1995. 
https://doi.org/10.5194/se-2019-179

Preprint. Discussion started: 4 December 2019

(c) Author(s) 2019. CC BY 4.0 License.

(c) (i)

van Keken, P. E., Hacker, B. R., Syracuse, E. M., and Abers, G. A.: Subduction factory: 4. Depth-dependent flux of H2O from subducting slabs worldwide, Journal of Geophysical Research, 116, https://doi.org/10.1029/2010jb007922, 2011.

Wang, C. Y.: Density and constitution of the mantle, Journal of Geophysical Research, 75, 3264-3284, https://doi.org/10.1029/JB075i017p03264, 1970.

Wang, T., Lin, J., Tucholke, B., and Chen, Y. J.: Crustal thickness anomalies in the North Atlantic Ocean basin from gravity analysis, Geochemistry, Geophysics, Geosystems, https://doi.org/10.1029/2010GC003402, 2011.

Wehrmann, H., Hoernle, K., Garbe-Schönberg, D., Jacques, G., Mahlke, J., and Kai, S.: Insights from trace element geochemistry as to the roles of subduction zone geometry and subduction input on the chemistry of arc magmas, International Journal of Earth Sciences, 103, 1929-1944, https://doi.org/10.1007/s00531-013-0917-1, 2014.

Weller, D. J., and Stern, C. R.: Along-strike variability of primitive magmas (major and volatile elements) inferred from olivinehosted melt inclusions, southernmost Andean Southern Volcanic Zone, Chile, Lithos, 296-299, 233-244, https://doi.org/10.1016/j.lithos.2017.11.009, 2018.

White, R. S., McKenzie, D., and O'Nions, R. K.: Oceanic crustal thickness from seismic measurements and rare earth element inversions, Journal of Geophysical Research Solid Earth, 97, 19683-19715, https://doi.org/10.1029/92JB01749, 1992.

Yogodzinski, G., and Kelemen, P.: Slab melting in the Aleutians: implications of an ion probe study of clinopyroxene in primitive adakite and basalt, Earth Planetary Science Letters, 158, 53-65, https://doi.org/10.1016/S0012-821X(98)00041-7, 1998.

Yogodzinski, G. M., Kay, R. W., Volynets, O. N., Koloskov, A. V., and Kay, S. M.: Magnesian andesite in the western Aleutian

500 Komandorsky region: Implications for slab melting and processes in the mantle wedge, Geological Society of America Bulletin, 107, 505-519, https://doi.org/10.1130/0016-7606(1995)107<0505:MAITWA>2.3.CO;2, 1995.

Yogodzinski, G. M., Lees, J. M., and Churikova, T. G.: Geochemical evidence for the melting of subducting oceanic lithosphere at plate edges, Nature, 409, 500-504, https://doi.org/10.1038/35054039, 2001.

Yogodzinski, G. M., Brown, S. T., Kelemen, P. B., Vervoort, J. D., Hoernle, K., and Portnyagin, M.: Role of Subducted Basalt 505 in the Genesis Island Arc Magmas: Evidence from Western Aleutian Seafloor Lavas, 2013,

Yogodzinski, G. M., Kelemen, P. B., Hoernle, K., Brown, S. T., Bindeman, I., Vervoort, J. D., Sims, K. W., Portnyagin, M., 
https://doi.org/10.5194/se-2019-179

Preprint. Discussion started: 4 December 2019

(c) Author(s) 2019. CC BY 4.0 License.

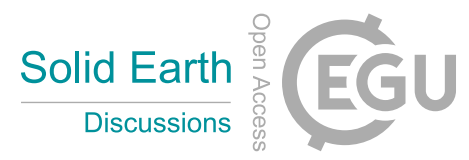

(c) (1)

and Werner, R.: Sr and O isotopes in western Aleutian seafloor lavas: Implications for the source of fluids and trace element character of arc volcanic rocks, Earth Planetary Science Letters, 475, 169-180, https://doi.org/10.1016/j.epsl.2017.07.007, 2017.

510 Zhang, H., Sun, Y., Tang, Y., Xiao, Y., Zhang, W., Zhao, X., Santosh, M., and Menzies, M. A.: Melt-peridotite interaction in the Pre-Cambrian mantle beneath the western North China Craton: Petrology, geochemistry and Sr, Nd and Re isotopes, Lithos, 149, 100-114, https://doi.org/10.1016/j.lithos.2012.01.027, 2012.

Zheng, Y., Chen, R., Xu, Z., and Zhang, S.: The transport of water in subduction zones, Science China Earth Sciences, 59, 651682, https://doi.org/10.1007/s11430-015-5258-4, 2016. 
https://doi.org/10.5194/se-2019-179

Preprint. Discussion started: 4 December 2019

(c) Author(s) 2019. CC BY 4.0 License.

Figure

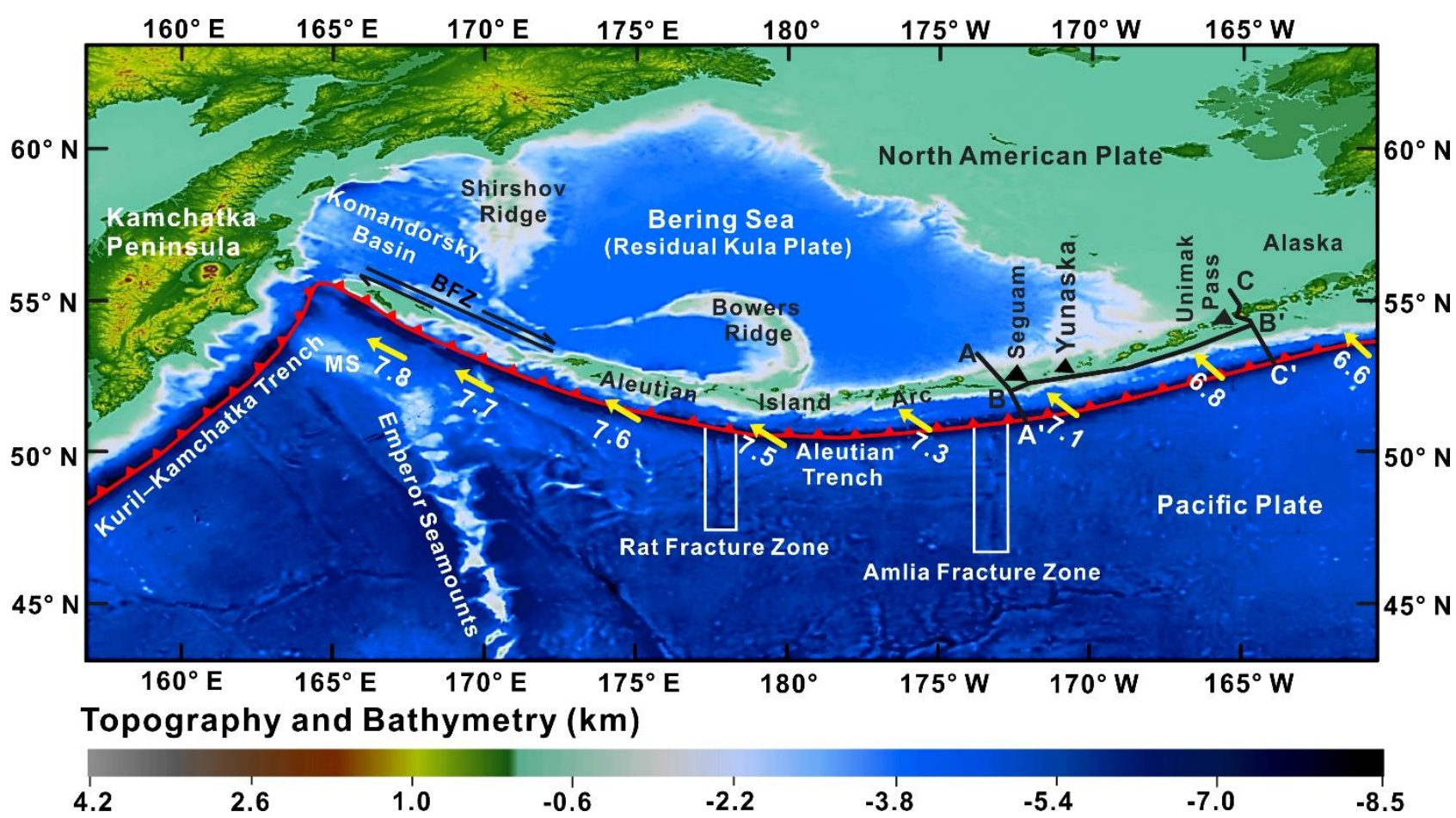

Figure 1. Topography and Bathymetry of the study area, which is released by Amante and Eakins.(2009). The three black solid lines represent

520 the wide-angle seismic lines AA', BB' and CC'. The yellow arrows show the slab convergence directions, and rates (Lay et al., 2017). The white rectangular frames are the fracture zones. BFZ: Bering Fracture Zone; MS: Meiji Seamounts. 
https://doi.org/10.5194/se-2019-179

Preprint. Discussion started: 4 December 2019

(c) Author(s) 2019. CC BY 4.0 License.

(c) (1)

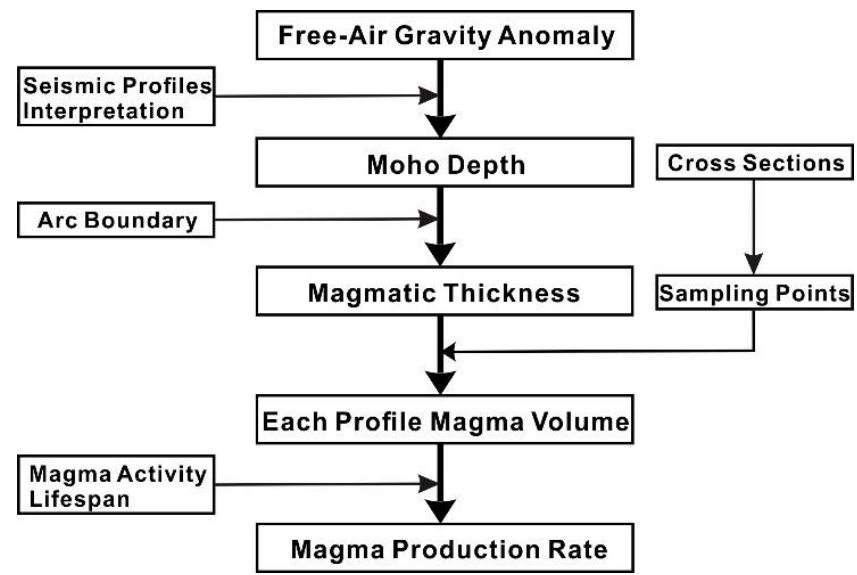

525 Figure 2. Island arc magma production rate estimation flow. The gravity effect of the different layers of the solid Earth is evaluated by density modeling, and thus, the gravity anomaly caused by the Moho undulations is isolated. The Moho depth can be inverted under the constraints of the seismic profiles. The accreted magma thickness is estimated based on the Moho undulations. Finally, the magma production rate variations along the island arc strike are obtained along different arc crossing sections, under the constraints of the island arc boundary and magmatic activity lifespan. 
https://doi.org/10.5194/se-2019-179

Preprint. Discussion started: 4 December 2019

(c) Author(s) 2019. CC BY 4.0 License.

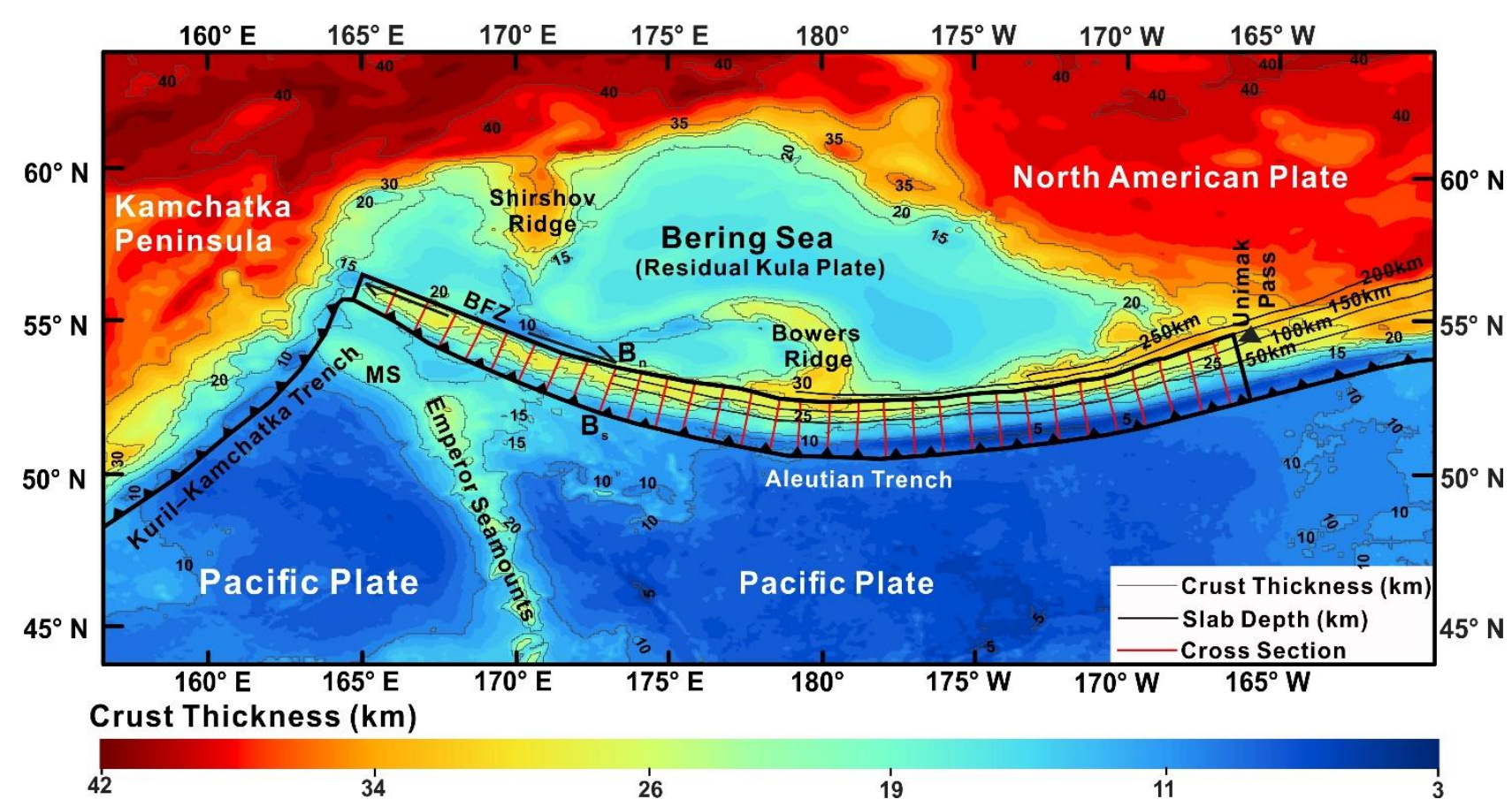

Figure 3. Crustal thickness map, which represents the vertical distance between the sediment bottom and the Moho interface. The Moho depth is obtained by gravity based on lithospheric density modeling. The thick black lines limit the boundary of the intra-oceanic subduction part of the Aleutian island arc. The labeled gray solid lines represent the contour of crust thickness. The labeled black lines represent the subducted slab depths. The labeled red lines are the cross sections along the arc strike. MS: Meiji Seamounts; BFZ: Bering Fracture Zone. 


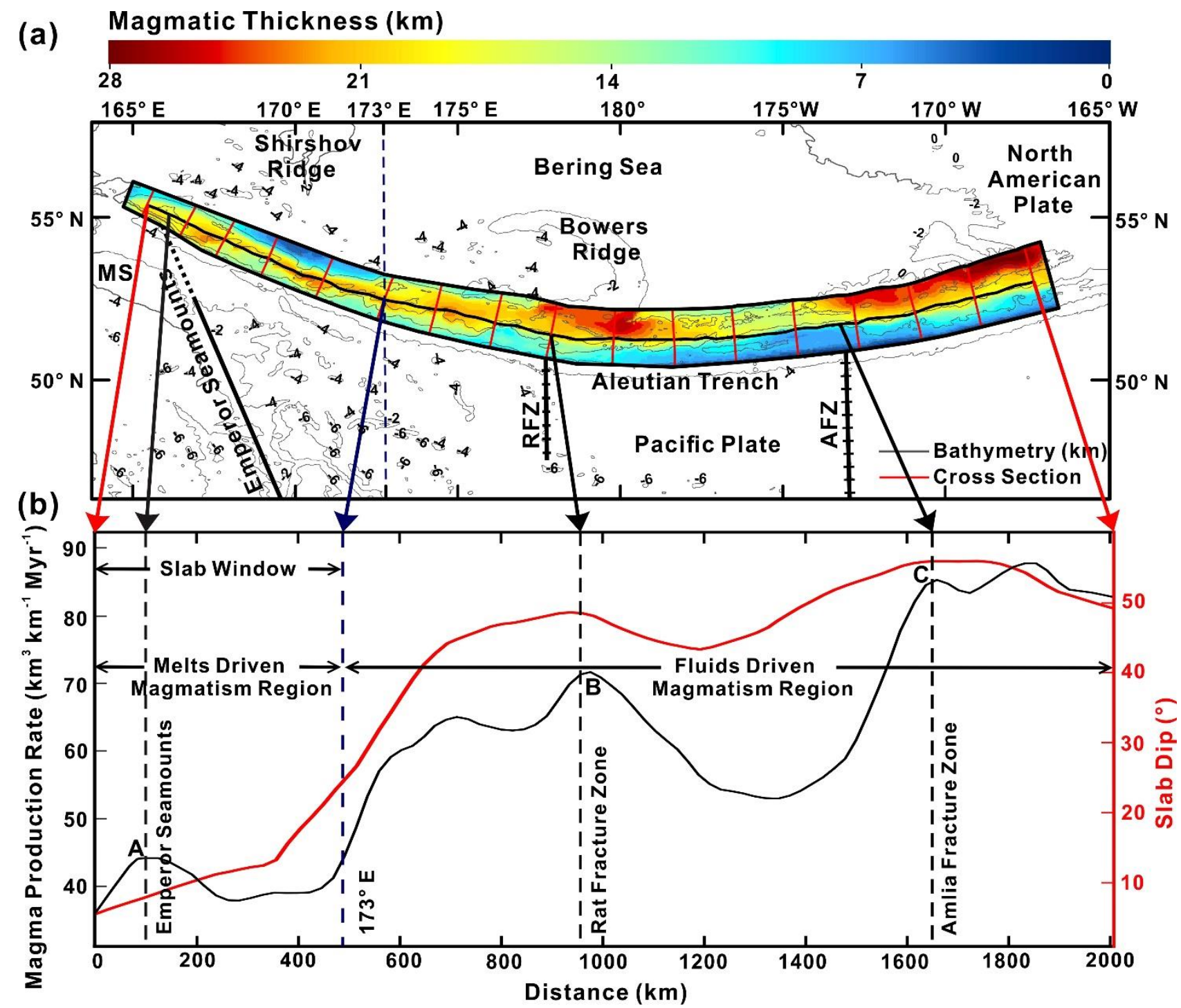

Figure 4. (a) Magmatic thickness is obtained by removing the original oceanic crustal thickness of $6 \mathrm{~km}$ from the current arc thickness. The black dotted line represents the extension of the Emperor Seamounts Chain. (b) The island arc magma production rates and slab dips along the Aleutian arc. The black solid curve indicates the island arc magma production rates, and the red solid curve indicates the slab dips (Hayes are the same with as in Fig. 3. 

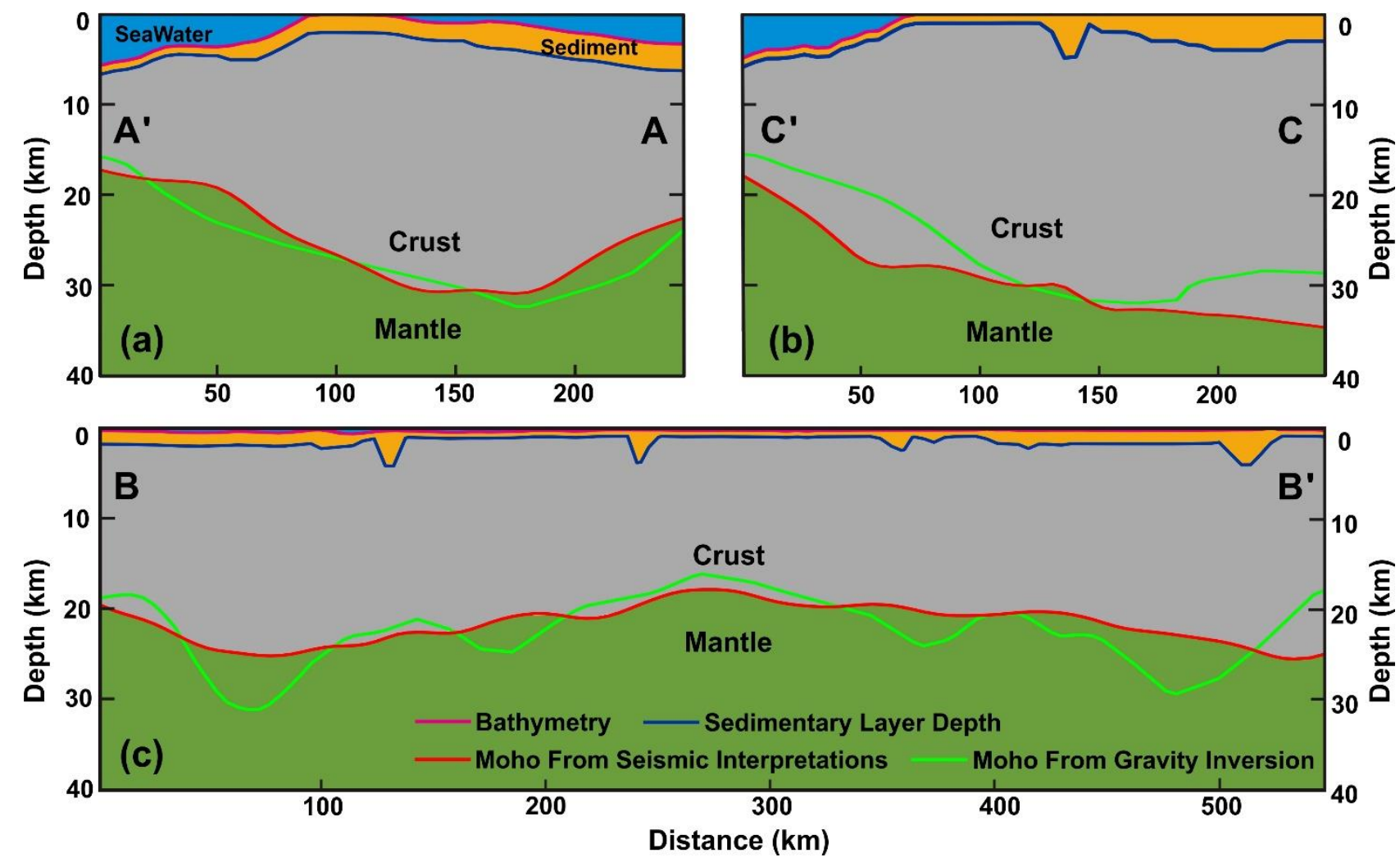

Figure 5. Contrast between the Moho geometries from the seismic interpretations and gravity inversion along the three seismic lines whose locations are shown in Fig. 1 (Calvert, 2011). Bathymetry is from ETOPO1 (Amante and Eakins, 2009) and sediment thickness is by Straume 545 et al. (2019). 
(a) Low-dip Subduction

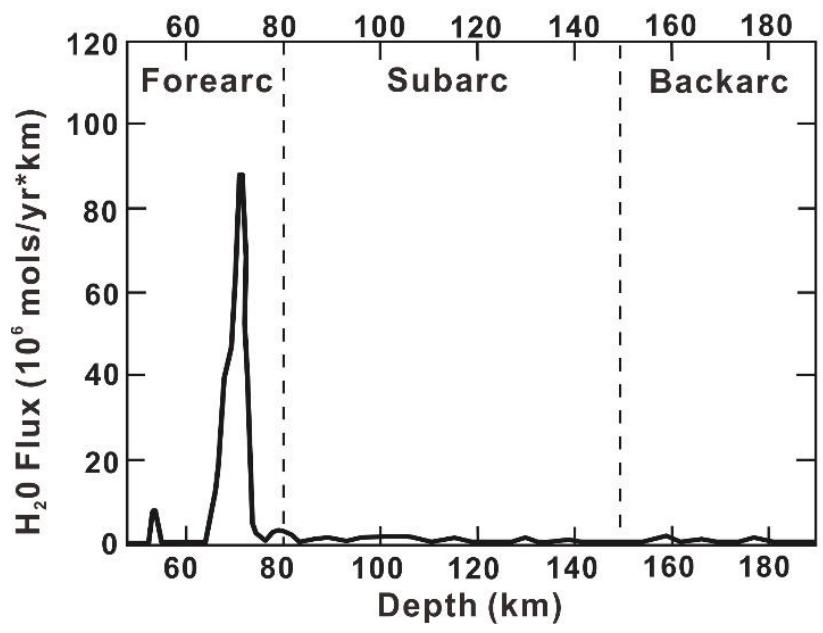

(b) High-dip Subduction

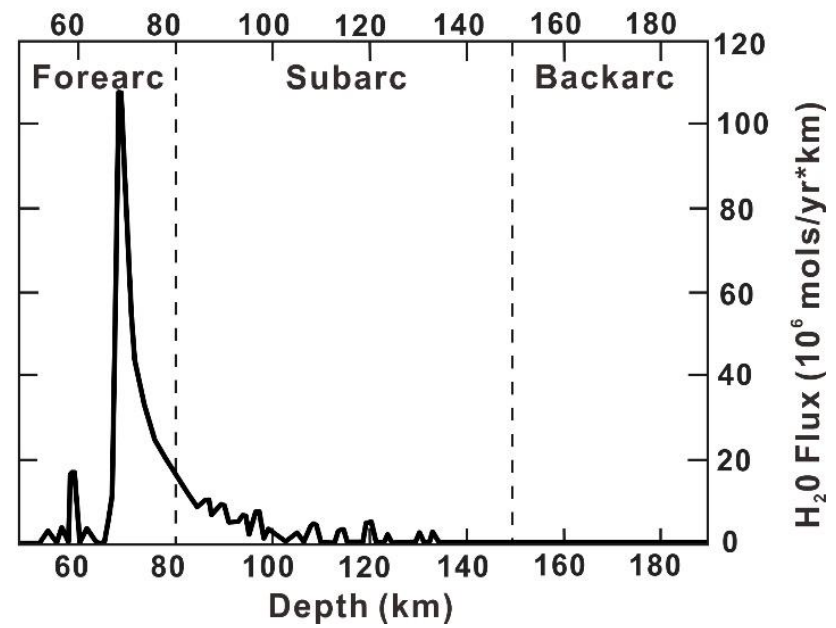

Figure 6. Water flux variations at different depths for low-dip (a) and high-dip (b) subduction after Gorman et al. (2006). The Water flux increase with the increase of slab dip. Approximately $90 \%$ of the water is released under the forearc region (depth less than $80 \mathrm{~km})$, and approximately $10 \%$ are released under the island arc (depth between 80 and $150 \mathrm{~km}$ ), very limited parts are lost under the back arc basin (depth greater than $150 \mathrm{~km}$ ). 
(a) Low-dip Subduction

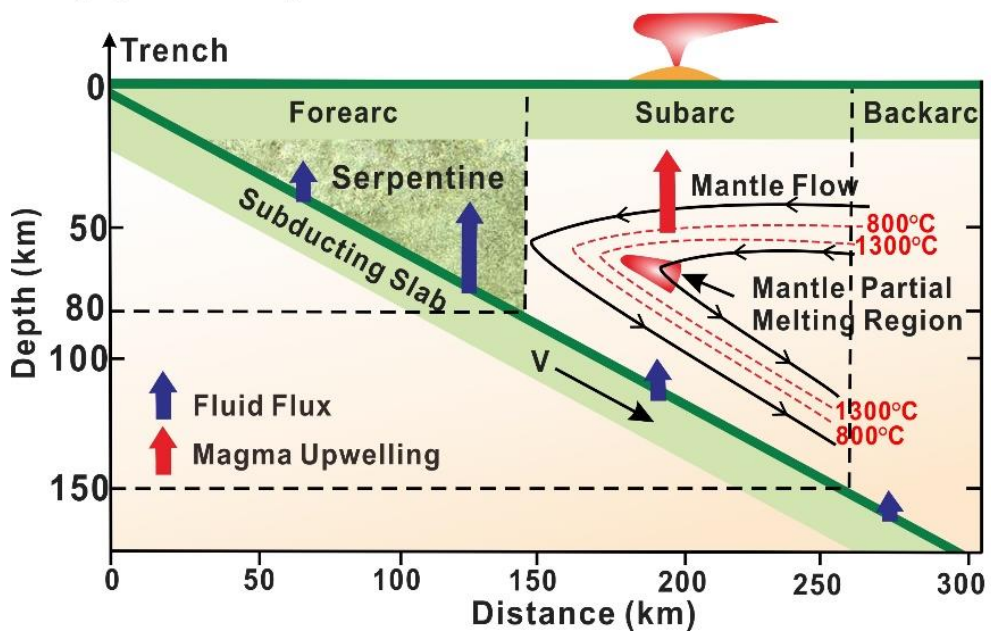

(b) High-dip Subduction

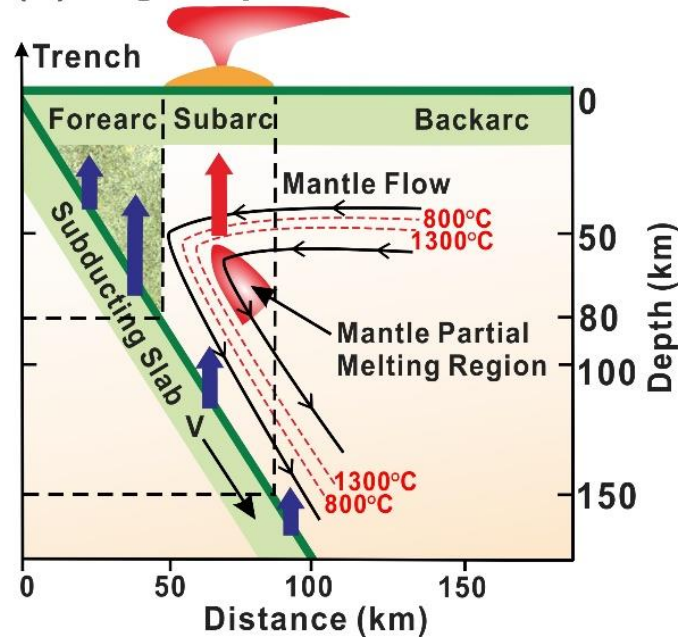

Figure 7. The island arc magma formation for low-dip (a) and high-dip (b) subduction after Schmidt and Poli. (1998). The black arrow

indicates the mantle flow direction. The water flux at the subarc depths of high-dip subduction is greater than that of at the low-dip subduction.

More water flux at the subarc depths means more mantle partial melting and more island arc magmatism to island arc. 


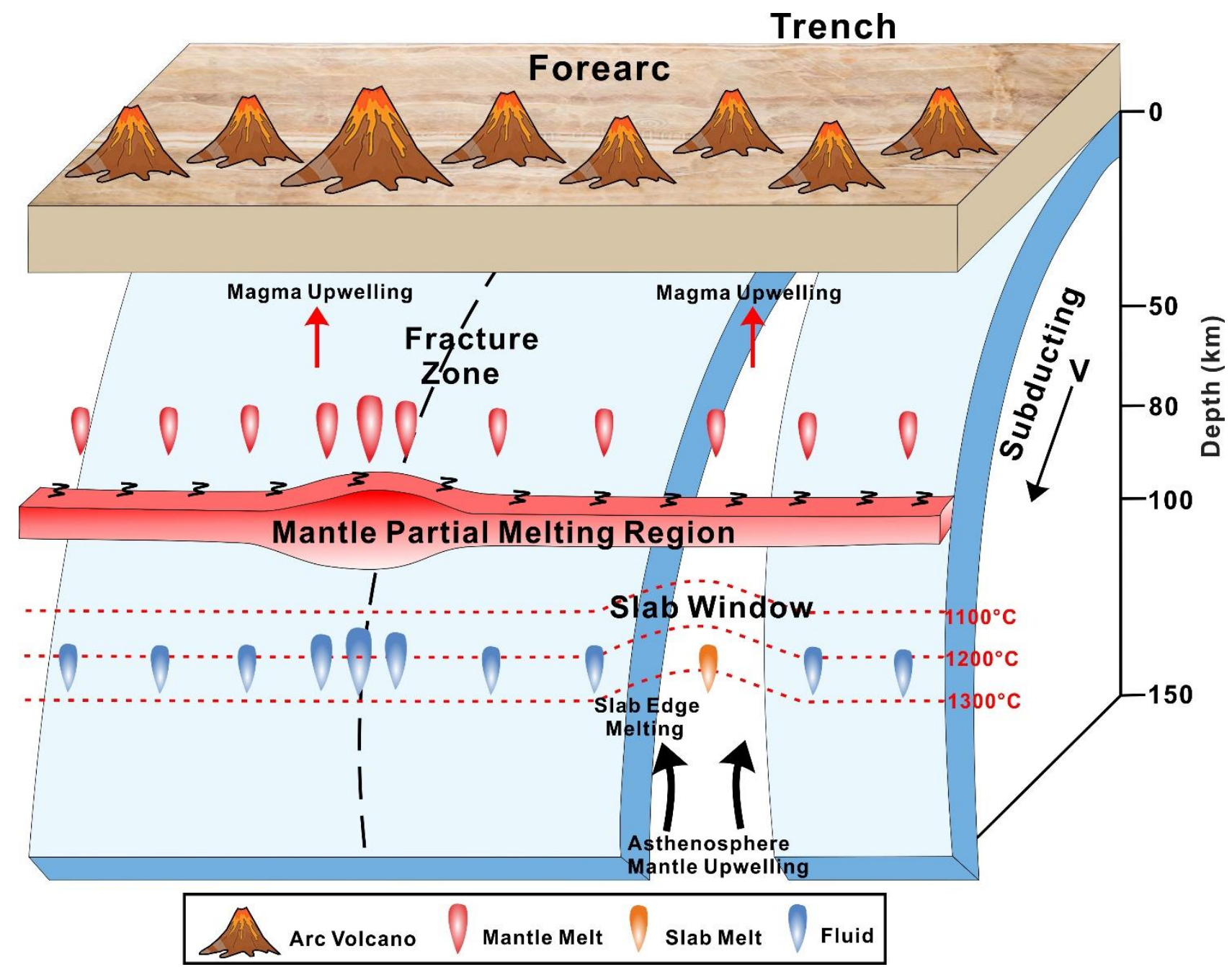

Figure 8. The 3D cartoon of island arc magmatism when there are is a fracture zone subduction and a slab window. The fluids and melts represent the parts which can contribute to the island arc magmatism. The fracture zone would supply more fluids because of the formation

of serpentine by hydrothermal alteration near or on the slab surface. At the location of the slab window, the asthenosphere mantle upwells, resulting in melting of the exposed slab edge. Fluids and melts from the subducted slab upwell to the mantle wedge and induce mantle partial melting of the mantle. The molten mantle then would then contribute to island arc magmatism. 